\title{
Relationship between carbon dioxide in Balcarka Cave and adjacent soils in the Moravian Karst region of the Czech Republic
}

\author{
Jiří Faimon ${ }^{1}$, Monika Ličbinská ${ }^{1,2}$, and Petr Zajiččk ${ }^{3}$
}

\begin{abstract}
:
Faimon J., Ličbinská M. and Zajíček P. 2012. Relationship between carbon dioxide in Balcarka Cave and adjacent soils in the Moravian Karst region of the Czech Republic. International Journal of Speleology, 41(1), 17-28. Tampa, Florida (USA). ISSN 03926672. http://dx.doi.org/10.5038/1827-806X.41.1.3

Carbon dioxide concentration, air temperature, and humidity were monitored at (1) two cave sites and (2) three adjacent karst soils. The data over a one-year period are supported by dripwater chemistry and cave visiting frequency. The results indicate that the sources of cave $\mathrm{CO}_{2}$ are anthropogenic and epikarstic ones in addition to ordinary soils. Epikarstic $\mathrm{CO}_{2}$ produced under almost stationary conditions probably control dripwater chemistry and cave's $\mathrm{CO}_{2}$ maxima. Based on breathing and door opening, anthropogenic activity affects instantaneous cave $\mathrm{CO}_{2}$ levels, depending on site volume/position and visitor number. A conceptual model of the $\mathrm{CO}_{2}$ dynamics of the soil-cave system is proposed. The study indicates that karst processes such as limestone dissolution and speleothem growth need not be entirely/directly controlled by external climatic conditions.
\end{abstract}

Keywords: $\mathrm{CO}_{2}$; cave; dripwater; epikarst; soil; visitors; Moravian Karst; Czech Republic

Received 7 October 2010; Revised 6 December 2010; Accepted 30 April 2011

\section{INTRODUCTION}

Recently, growing interest has been seen in using speleothems as an archive of paleoenvironmental information (see Fairchild et al., 2006, for a review). To take advantage of the paleoproxies, a better understanding of speleothem growth mechanisms/ dynamics is required. Carbon dioxide is one of the most important variables controlling growth. A consensus exists that the difference between soil and cave $\mathrm{CO}_{2}$ partial pressures drives dripwater degassing and, consecutively, dripwater supersaturation with respect to calcite. (Dreybrodt, 1999; Baldini et al, 2008). Despite great effort, many problems such as $\mathrm{CO}_{2}$ source origin and $\mathrm{CO}_{2}$-dynamics in the exteriorsoil-epikarst-cave-exterior chain have been neglected. Generally, karst soils are believed to be the main sources of cave $\mathrm{CO}_{2}$. However, based on various indices, an ever stronger reservation appears about this belief.

\footnotetext{
${ }^{1}$ Department of Geological Sciences, Faculty of Sciences, Masaryk University, Kotlářská 2, 61137 Brno, Czech Republic. (faimon@sci.muni.cz)

2Institute of Geological Engineering, Faculty of Mining and Geology, VŠB - Technical University of Ostrava, 17. listopadu 15, 70833 Ostrava - Poruba, Czech Republic. (monika.licbinska@vsb.cz)

${ }^{3}$ Cave Administration of the Czech Republic, Svitavská 11/13, 678 01 Blansko, Czech Republic. (zajicek@caves.cz)
}

Soil $\mathrm{CO}_{2}$ production is derived from (1) respiration of autotrophs (root respiration and rhizomicrobial respiration) and (2) respiration of heterotrophs (Kuzyakov \& Larionova, 2005; Kuzyakov, 2006). Output from soils is linked to (i) diffusion into the external atmosphere (Piao at al., 2000; Arnold et al., 2005; Jungkunst et al., 2008; Longdoz et al., 2008); (ii) diffusion into the voids in underlying rocks, and to (iii) dissolution in percolating waters (Kaufmann \& Dreybrodt, 2007). In general, $\mathrm{CO}_{2}$ concentrations in the soil atmosphere are estimated to range from 0.1 to $10 \%$ vol. (Miotke, 1974; Troester \& White, 1984). However, direct measurements in karst soils indicate a much narrower range, of between 0.1 and $1.0 \%$ vol. (Bourges et al., 2001; Spötl et al., 2005). Soil $\mathrm{CO}_{2}$ concentrations show strong seasonality (Spötl et al., 2005). Annual production reflects external climatic conditions (Jassal et al., 2005; Li et al., 2008; Iqbal et al., 2008). A review of $\mathrm{CO}_{2}$ behavior in ecosystems on global scale is given in Baldocchi et al. (2001).

$\mathrm{CO}_{2}$ input into cave includes (1) natural fluxes associated with (i) direct diffusion from soils/epikarst, (ii) microbial decay of organic matter in cave sediments, (iii) respiration of animals, (iv) endogenous $\mathrm{CO}_{2}$, (vi) dripwater degassing (Holland et al., 1964), and (2) anthropogenic flux stemming from a person exhaling (Faimon et al., 2006). $\mathrm{CO}_{2}$ output from the cave is connected with airflows that carry $\mathrm{CO}_{2}$ out of the cave (cave ventilation). Cave airflows are controlled by cave geometry and by pressure/temperature gradients 
between the cave and the exterior (de Freitas et al., 1982; Baker \& Genty, 1998; Bourges et al., 2001; Spötl et al., 2005; Faimon et al. 2006; 2011). When the cave $\mathrm{CO}_{2}$ level increases, the $\mathrm{P}_{\mathrm{CO} \text { (soil) }}-\mathrm{P}_{\mathrm{CO} \text { (cave) }}$ difference diminishes and the driving force for speleothem growth falls. In contrast, a cave $\mathrm{CO}_{2}$ level decrease enhances the difference and, consecutively, also the driving forces. Analogically to soil levels, cave $\mathrm{CO}_{2}$ levels show seasonal variations (Troester \& White, 1984; Ek \& Gewelt, 1985; Bourges et al., 2001; Spötl et al., 2005). In the cave atmosphere, $\mathrm{CO}_{2}$ levels vary within a range from 0.1 to $1.0 \%$ vol. (e.g. Tatár et al., 2004; Baldini et al., 2006). Levels exceeding $1 \%$ vol. were also monitored in some caves (e.g., Batiot-Guilhe et al., 2007). Recently, Faimon \& Ličbinská (2010) try to relate the trends in soil and cave $\mathrm{CO}_{2}$ levels at selected sites of Moravian Karst.

The goal of the study was (1) to verify $\mathrm{CO}_{2}$ levels in different karst soils and (2) to try to identify their effect on cave $\mathrm{CO}_{2}$ during year period.

\section{SITE OF STUDY}

The Moravian Karst is the most extensive karst area in the Czech Republic (Balák, 1999). It is a part of the Drahany Highlands. The Moravian Karst forms a belt $3-5 \mathrm{~km}$ wide and $25 \mathrm{~km}$ long, covering an area of $94 \mathrm{~km}^{2}$. The Lažánky and Vilémovice limestones of the Macocha Formation (Middle/ Upper Devonian age) are typical karst rocks at the sites (calcite content varies from 95 to $99 \% \mathrm{wt}$ ). Total rock thickness is estimated to be $500-1000 \mathrm{~m}$. The Karst plateau altitude varies between 250 and $600 \mathrm{~m}$ a.s.1. Annual precipitation is about $650 \mathrm{~mm}$. Annual regional temperature is about $10^{\circ} \mathrm{C}$. Rendzic Leptosols are the main soil types that have evolved on the limestones. Granitoid rocks of the Brno Crystalline Massif (Proterozoic) build a crystalline basement.

The sites of the study, Balcarka Cave and the soils above the cave are in the northern part of the Moravian Karst near the village of Ostrov $u$ Macochy (Fig. 1). The cave is open to tourists with a visitor rate of 30-40 thousand persons per year. The thickness of overburden is about $20-50$ meters. The cave monitoring sites were in the Discoverers' Chimney Chamber (C1) and Large Foch's Hall (C2).

Based on the FAO World Reference Base classification, uniform international soil taxonomy for communication between specialists in different branches of science, (IUSS Working Group WRB, 2007), three soil types were monitored in the area above Balcarka Cave (Fig. 1): Anthrosol (S1), lithic Leptosol (S2), and brown rendzic Leptosol (S3). The Anthrosol S1 was farmed and altered by tilling in the past. Nowadays, it is used as a pasture/meadow. Lithic Leptosol S2 is the soil of the karst meadow. It is more skeletal; the humus horizon (A-horizon) is only $5-10 \mathrm{~cm}$ thick and proceeds directly into the bedrock. The brown rendzic Leptosol S3 is formed in a mixed forest. This soil type has a mollic horizon that contains or immediately overlies calcaric materials or calcareous rock containing 40 percent or more calcium carbonate equivalent. A summary of the monitoring sites, the character of vegetation, soil types and cave details are given in Tables 1 and 2 .

\section{METHODS}

$\mathrm{CO}_{2}$ concentrations, air temperature and humidity were monitored at approximately 15-day intervals in the soil and cave atmospheres during the years 2006-2007. Soil atmosphere variables were monitored in probe holes drilled down to the $\mathrm{C}$-horizon by steel bar (ø $5 \mathrm{~cm})$. The wall of each probe hole was reinforced with a cylinder of polyethylene netting and sealed with a plastic cover.

Cave atmosphere variables were monitored at a height of 1 metre above the cave floor. An impact of diurnal variability in $\mathrm{CO}_{2}$ concentrations were damped to some extent by monitoring in the narrow time range between 10:00 and 14:00.

$\mathrm{CO}_{2}$ concentrations were measured in situ by 2-channel IR-detector FT A600-CO2H linked with ALMEMO 2290-4 V5, Ahlborn, Germany (measuring range: 0 to 10,000 ppmv; accuracy: \pm 50 ppmv +2 vol. \% of measured value in the range of 0 to 5000 ppmv; resolution: 1 ppmv or 0.0001 vol \%). The relative humidity and temperature of the soil and cave atmosphere were monitored by digital hydro/ thermometer GFTH 200, Greisinger electronic $\mathrm{GmbH}$, Germany (resolution: $0.1 \% \mathrm{RH}$ and $0,1^{\circ} \mathrm{C}$;

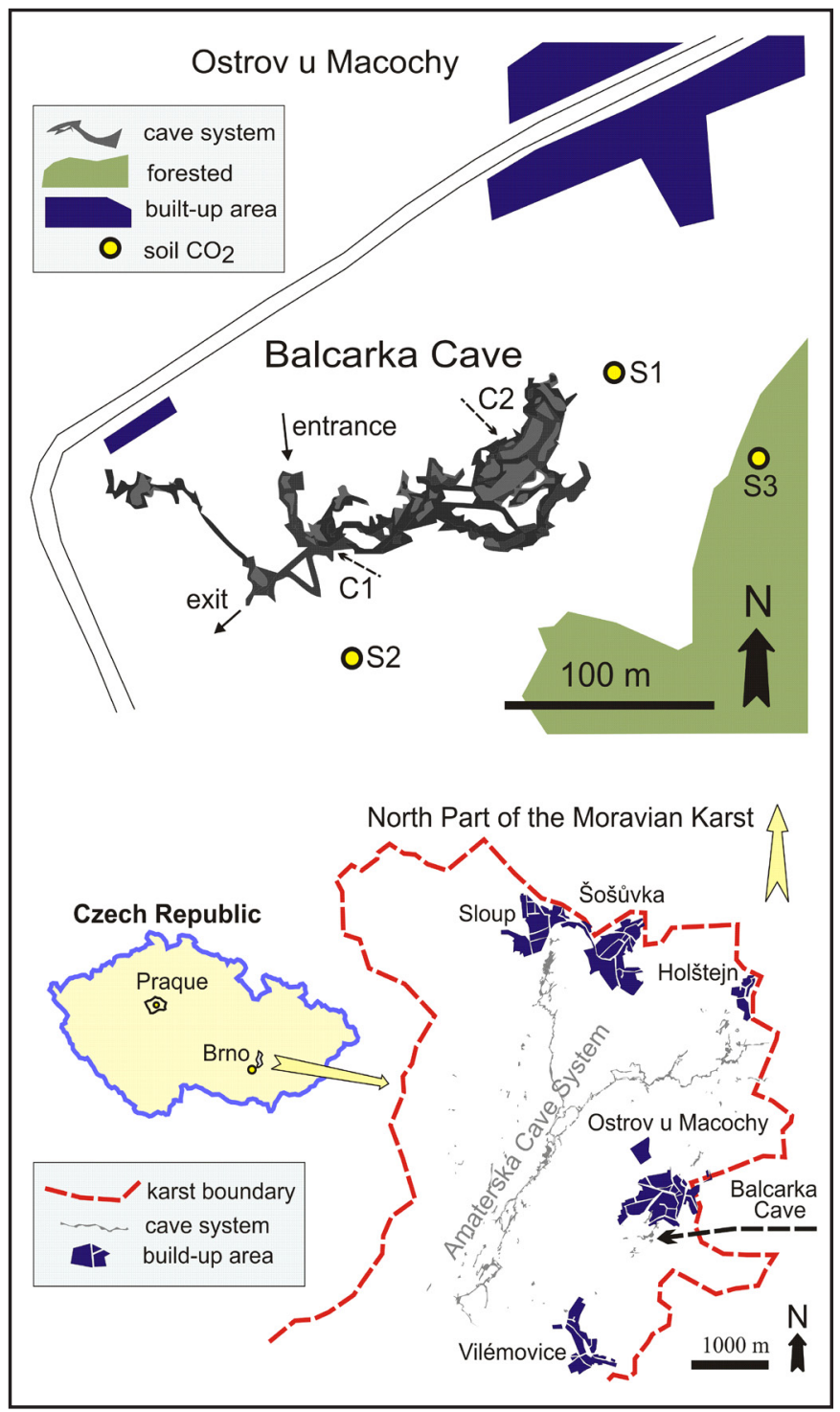

Fig.1. Sketch map of monitoring sites. For explanation of the abbreviations, see Tab.1. 
Table 1. Parameters of the cave monitoring sites.

\begin{tabular}{|c|c|c|c|c|c|}
\hline Code & Detailed & $\begin{array}{c}\text { Rectangular projection } \\
\text { area }\left[\mathrm{m}^{2}\right]\end{array}$ & $\begin{array}{c}\text { Volume } \\
{\left[\mathrm{m}^{3}\right]}\end{array}$ & Cave type & $\begin{array}{c}\text { Overburden } \\
{[\mathrm{m}]}\end{array}$ \\
\hline $\mathrm{C} 1$ & Discoverers' Chimney Chamber & 91 & 634 & dynamic & 30 \\
\hline C2 & Large Foch's Hall & 1223 & 14674 & dynamic(?) & 40 \\
\hline
\end{tabular}

Table 2. Parameters of the monitored soils.

\begin{tabular}{|c|c|c|c|c|c|c|}
\hline Code & Detailed & Soil type $e^{(a)}$ & $\begin{array}{c}\text { Hillslope } \\
\text { [degree] }\end{array}$ & $\begin{array}{c}\text { SPD }^{(b)} \\
{[\mathrm{m}]}\end{array}$ & $\begin{array}{l}\text { Air-filled } \\
\text { porosity }{ }^{(c)}\end{array}$ & $\begin{array}{c}\text { Pore volume } \\
{\left[\mathrm{m}^{3} \mathrm{~m}^{-2}\right]}\end{array}$ \\
\hline $\mathrm{S} 1$ & anthropogenic soil(d) $^{(\mathrm{s})}$ & Anthrosol & $<5$ & 0.4 & 0.07 & 0.028 \\
\hline S2 & karst meadow soil & lithic Leptosol & $<5$ & 0.2 & 0.20 & 0.04 \\
\hline S3 & mixed forest soil & $\begin{array}{l}\text { brown rendzic } \\
\text { Leptosol }\end{array}$ & $<5$ & 0.5 & 0.20 & 0.10 \\
\hline
\end{tabular}

(a) based on FAO WRB (IUSS Working Group WRB, 2007)

b) soil profile depth

measuring range: temp: -25 to $+70{ }^{\circ} \mathrm{C}$; $\mathrm{RH}: 0$ to 100 $\%$; temperature accuracy: $\pm 0.5 \%$ of measured value $\pm 0.1^{\circ} \mathrm{C}$; humidity accuracy: $\pm 1.5 \%$ linearity, $\pm 1.5 \%$ hysteresis for $11-90 \%$ range).

Dripwater samples were collected in the Large Foch's Hall during the years 2003-2004. In the cave, pH (WTW pH 330i), Ca (complexometric microtitration), and alkalinity (acidimetric microtitration) were determined. Subsequently, the waters were analyzed in the laboratory for $\mathrm{K}, \mathrm{Mg}, \mathrm{Na}(\mathrm{AAS}), \mathrm{NH}_{4}^{+}, \mathrm{NO}_{2}^{-}$, $\mathrm{PO}_{4}{ }^{3-}, \mathrm{NO}_{3}^{-}$(spectrophotometry), $\mathrm{SO}_{4}{ }^{2-}$, and $\mathrm{Cl}^{-}$ (microtitration). The estimated analytical errors are below $5 \%$.

The data analysis was evaluated in the STATISTICA code (StatSoft, Inc., www.statsoft.cz). The nonparametric Kendall's test was conducted by using computer code developed by the United States Geological Survey (USGS) (Helsel et al., 2006). The data on dripwater geochemistry were evaluated in the PHREEQC code (Parkhurst \& Appelo, 1999).

\section{Soil data}

\section{RESULTS}

The evolution of $\mathrm{CO}_{2}$ concentration, temperature, and relative humidity in the studied soils $\mathrm{S} 1, \mathrm{~S} 2$, and S3 over a one-year period is given in Fig. 2. All the variables show a strong seasonality. The patterns of $\mathrm{CO}_{2}$ and temperature are mutually similar (Fig. 2C, $\mathrm{B})$, whereas the pattern of relative humidity is inverse (Fig. 2A).

Air relative humidity HS1, HS2, and HS3 in soils $\mathrm{S} 1, \mathrm{~S} 2$, and $\mathrm{S} 3$, respectively, varied between 40 and $80 \%$ (Fig. 2A). An extensive maximum is obvious during the long-term period, from October 06 to May 07. Minima were registered in summer (July 06 and August 07). A shallow local minimum in January 07 (Fig. 2A) is roughly consistent with the subfreezing temperature.

Air temperatures TS1, TS2, and TS3 in soils S1, $\mathrm{S} 2$, and S3, respectively, followed the external daily temperature T(ext) (Fig. 2B). It approached/exceeded $30^{\circ} \mathrm{C}$ in July 06 and dropped below freezing point in February 07 (Fig. 2B). (c) estimated, based on Reynolds et al. (2007)

(d) formerly cultivated/tilled soil, presently meadow
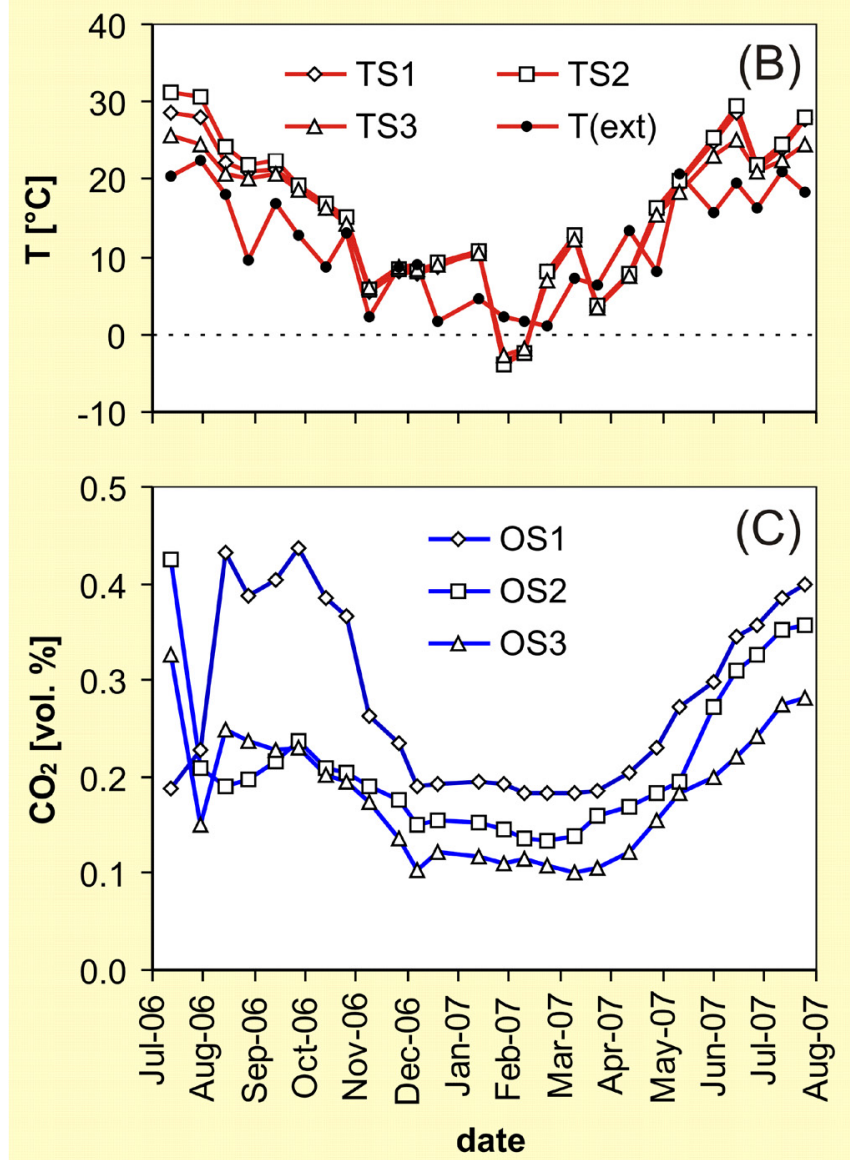

Fig. 2. Soil data (the sites S1, S2, S3 above Balcarka Cave). (A) air relative humidity, $(\mathrm{B})$ air temperature, $(\mathrm{C})$ air $\mathrm{CO}_{2}$-concentration. 
The $\mathrm{CO}_{2}$ concentrations OS1, OS2, and OS3 in soils $\mathrm{S} 1, \mathrm{~S} 2$, and $\mathrm{S} 3$, respectively, are ordered from the highest to the lowest in the sequence OS1 >>OS2>OS3. The maxima (between 0.4 and $0.5 \%$ vol.) were reached during late summer/early autumn(July to October 06). In summer 06, the OS1 maxima exceeded OS2 and OS3 by a factor of 2. Minima (between 0.1 and $0.2 \%$ vol.) were monitored during winter/early spring (December 06 to March/April 07). The lowest $\mathrm{CO}_{2}$ concentrations were registered in mixed forest soils (S3) during winter (Fig. 2C). Surprisingly, a local minimum appeared in the first days of August 06. It is roughly consistent with the minimum of soil air humidity.

\section{Cave data}

Both the $\mathrm{CO}_{2}$ concentrations and number of visitors show a strong seasonality (Fig. 3). In contrast, the cave temperature hardly changes in either cave site. During the whole monitoring period, the cave temperatures in both cave sites differed: the temperature in $\mathrm{C} 1, \mathrm{TC} 1 \sim 12.3 \pm 0.35^{\circ} \mathrm{C}$ systematically exceeded the temperature in $\mathrm{C} 2, \mathrm{TC} 2 \sim 10.6 \pm .0 .36^{\circ} \mathrm{C}$
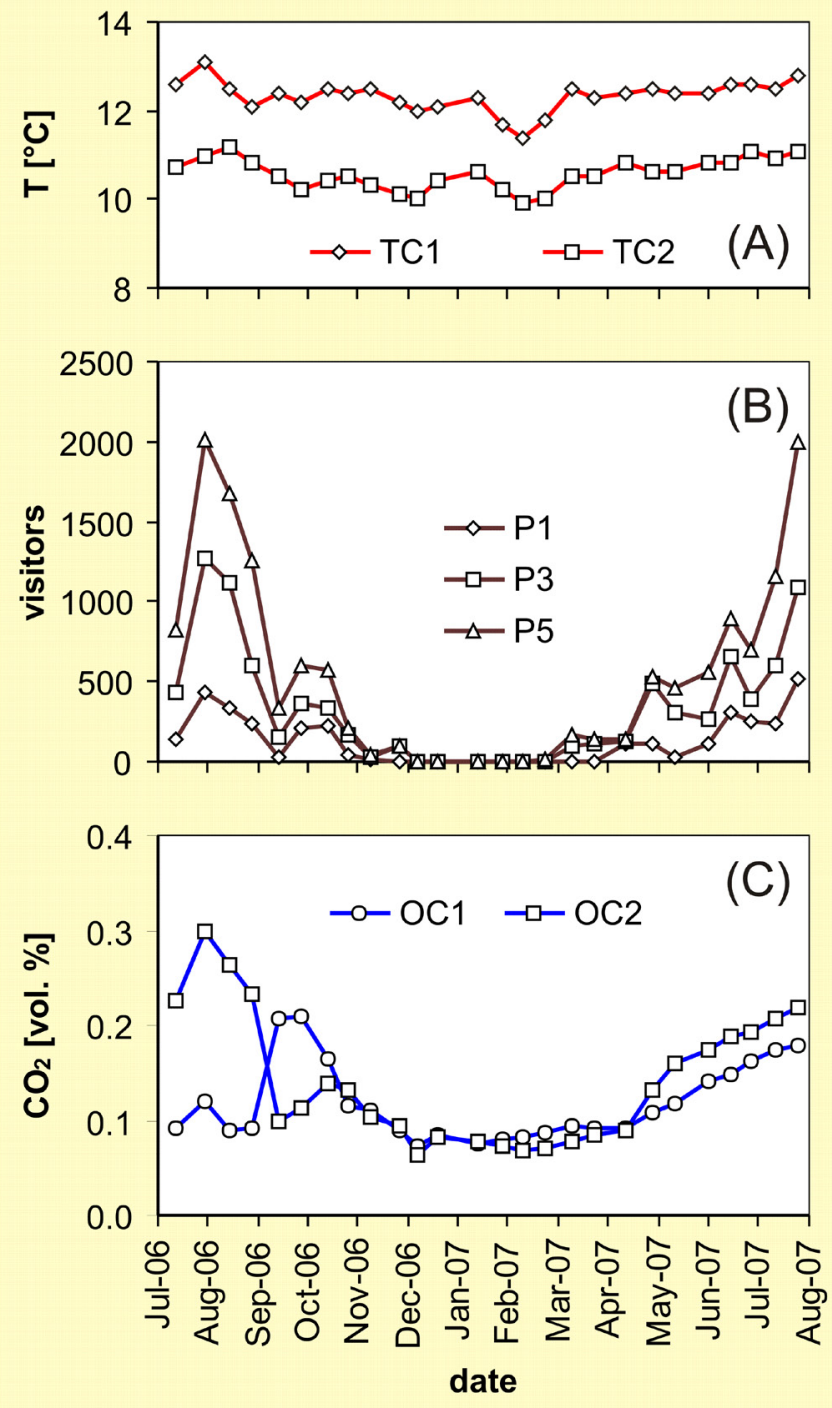

Fig. 3. Balcarka Cave data (the sites $\mathrm{C} 1$ and $\mathrm{C} 2$ ). (A) air temperatures TC1 and TC2; (B) visitor numbers per day (P1), three days (P3), five days (P5); (C) air $\mathrm{CO}_{2}$-concentrations OC1 and OC2.
(Fig. 3A). The local minimum in February 07 is roughly consistent with the external temperature minimum.

The anthropogenic $\mathrm{CO}_{2}$ impact is quantified by the $\mathrm{P} 1, \mathrm{P} 3$, and $\mathrm{P} 5$ variables that correspond to the visitor numbers per given day, preceding 3 days, and 5 days, respectively. The cumulative variables are necessary because of unknown extent of cave ventilation effect on anthropogenic $\mathrm{CO}_{2}$ (cave relaxation). The evolution of the variables P1, P3, and P5 during the studied period is presented in Fig. 3B. As can be seen, the visitor number was at maximum in August. In contrast, it was near zero in winter (from November to March).

The $\mathrm{CO}_{2}$ levels were systematically higher in deeper cave passages (C2) excluding the September-October period with inverse levels. Maximum carbon dioxide concentrations (up to $0.3 \%$ vol.) were examined for the summer-early autumn(July to September) period of 2006. The results show that surprisingly low values occur at site C1. Minima (below $0.1 \%$ vol.) were observed during the winter/early spring period (from December to April) (Fig. 3C).

The composition of two drips, D1 (four samples) and D2 (eight samples) is given in Fig. 4. Their $\mathrm{pH}$ is near 8 , calcium and carbonate species (alkalinity) are dominant $\left(10^{-3}\right.$ to $\left.10^{-2} \mathrm{~mol} / \mathrm{L}\right)$, other species $(\mathrm{K}, \mathrm{Mg}$, $\mathrm{Na}$, nitrate, chloride, sulfate) are minor $\left(10^{-5}\right.$ to $10^{-4}$ $\mathrm{mol} / \mathrm{L}$ ). The remaining species (ammonium, nitrite, and phosphate) are in concentrations about/below $10^{-6} \mathrm{~mol} / \mathrm{L}$.

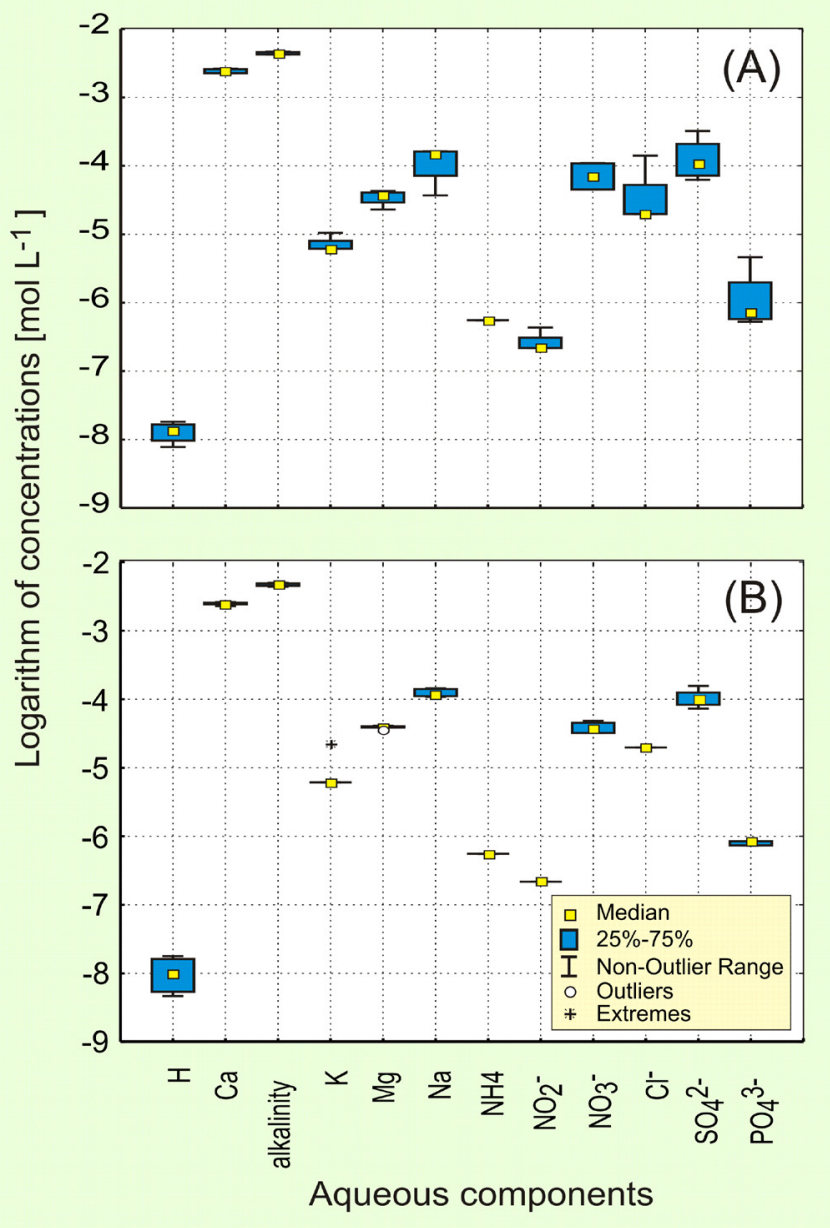

Fig. 4. Dripwater composition (Large Foch's Hall, Balcarka Cave). (A) drip D1 (4 samples); (B) drip D2 (8 samples). 


\section{DATA ANALYSIS}

There were derived two additional variables: |DTi|, which is an absolute value of the temperature gradient between exterior and cave, $|\mathrm{DTi}|=\mid \mathrm{T}(\mathrm{ext})-$ TCi|, and AHSi, which is soil air absolute humidity. All variables were arranged into two groups, the one potentially controlling soil $\mathrm{CO}_{2}$, i.e., TSi, $\mathrm{T}(\mathrm{ext})$, and AHSi, and the one potentially controlling cave $\mathrm{CO}_{2}$, i.e., OSi, |DTi|, T(ext), and Pi).

\section{Correlation analysis}

Based on linear interpolations, the original time series of single variables (raw data) were recalculated into equidistant ones with 15-day distance. A nonlinear trend/seasonality was determined as a central moving average of $3^{\text {rd }}$ order (CMA-3) and of $5^{\text {th }}$ order (CMA-5) (see Alvarez-Ramirez et al., 2005). Alternatively, the trend was identified by data regression with the polynomial of $4^{\text {th }}$ order (PN-4). Each individual trend was subtracted from the equidistant data to prevent trend impact on correlations of variables. The resulting detrended/ residual data sets were checked for stationarity by non-parametric Kendall's test (see Hirsch et al., 1982; Hirsch \& Slack, 1984; Helsel \& Hirsch, 2002; Helsel \& Frans, 2006). Finally, the obtained stationary data (SD-CMA-3, SD-CMA-5, SD-PN-4) were analyzed for long-range cross-correlations. The results are in the Table 3. Surprisingly, no correlations exist between the soil $\mathrm{CO}_{2}$ concentrations and soil air temperature/ humidity. Weak positive correlations appear between the individual soil $\mathrm{CO}_{2}$ levels in dependence on the used detrending method. A clear correlation is between OS1 and OS3. In contrast, the correlations OS1/OS2 and OS2/OS3 resulting from SD-CMA-5 and SD-PN-4 are less evident.

Some correlations are found between soils and cave $\mathrm{CO}_{2}$. However, only the couples OS1/OC1 and OS2/OC2 show significant positive correlations regardless of detrending methods. Other correlations are ambiguous: OS2/OC1 (SD-PN-4 only), OS3/OC1 (SD-CMA-3 and SD-CMA-5), OS1/OC2 (SD-PN-4 and SD-CMA-5), and OS3/OC2 (SD-CMA-3, SD-CMA-5).

Positive correlations are evident also between the cave $\mathrm{CO}_{2}$ levels and attendance. OC1 is lagged against P1/P3/P5 and P5/OC1 correlates only in the $\mathrm{SD}-\mathrm{PN}-4$ set. In contrast, OC2 correlates with $\mathrm{P} 1 / \mathrm{P} 3 /$ P5 without any delay and regardless of detrending method. Except of the positive correlations, there are also negative correlations at different lags: whereas OC1 correlate with P1/P3 at small delay (lag -1) regardless of detrending methods, OC2 correlates convincingly only with P3 at much higher delay (lag $\sim-2$ to -3$)$.

No expected negative correlations exist between cave $\mathrm{CO}_{2}$ and temperature gradients or external temperature. A sign of negative correlation is between $\mathrm{T}(\mathrm{ext})$ and $\mathrm{OC} 1$ (SD-PN-4, p > 0.05).

To determine the weight of individual variables at different seasons, an attempt was made to segment the detrended data into the parts statistically homogenous by the method of entropy of curves (Denis \& Crémoux, 2002; Denis et al., 2005). However, it did not improve the results mainly due to high fragmentation of the series.
Table 3. Correlations between selected variables at $p<0.05$

\begin{tabular}{|c|c|c|c|c|c|c|c|}
\hline \multicolumn{2}{|c|}{ Variables } & \multicolumn{2}{|c|}{ SD-CMA- $3^{(a)}$} & \multicolumn{2}{|c|}{ SD-CMA-5(b) } & \multicolumn{2}{|c|}{ SD-PN-4(c) } \\
\hline first & lagged & LAG & 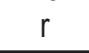 & $1 \wedge$ & 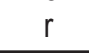 & & $r$ \\
\hline TS1 & OS1 & $\mathrm{N}$ & $\mathrm{N}$ & $N$ & $\mathrm{~N}$ & $\mathrm{~N}$ & $\mathrm{~N}$ \\
\hline TS2 & OS2 & $N$ & $\mathrm{~N}$ & 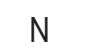 & $\mathrm{N}$ & $\mathrm{N}$ & $\mathrm{N}$ \\
\hline TS3 & OS3 & $\mathrm{N}$ & $\mathrm{N}$ & N & $\mathrm{N}$ & $\mathrm{N}$ & $\mathrm{N}$ \\
\hline AHS1 & OS1 & $\mathrm{N}$ & $\mathrm{N}$ & $\mathrm{N}$ & $\mathrm{N}$ & $\mathrm{N}$ & $\mathrm{N}$ \\
\hline AHS2 & OS2 & $\mathrm{N}$ & $\mathrm{N}$ & $\mathrm{N}$ & $\mathrm{N}$ & $\mathrm{N}$ & $\mathrm{N}$ \\
\hline AHS3 & OS3 & $\mathrm{N}$ & $\mathrm{N}$ & $\mathrm{N}$ & $\mathrm{N}$ & $\mathrm{N}$ & $\mathrm{N}$ \\
\hline OS1 & OS2 & 0 & 0.47 & 0 & -0.47 & 7 & 0.50 \\
\hline OS1 & OS3 & 0 & 0.78 & -1 & 0.60 & 0 & 0.48 \\
\hline OS2 & OS3 & 0 & 0.81 & $\mathrm{~N}$ & $\mathrm{~N}$ & 0 & 0.71 \\
\hline OS1 & OC1 & -2 & 0.67 & -2 & 0.45 & -2 & 0.48 \\
\hline OS2 & OC1 & $\mathrm{N}$ & $\mathrm{N}$ & 0 & 0.58 & $\mathrm{~N}$ & $\mathrm{~N}$ \\
\hline os3 & $\mathrm{OC} 1$ & -2 & 0.73 & $\mathrm{~N}$ & $\mathrm{~N}$ & -1 & $0.38^{(d)}$ \\
\hline OS1 & $O C$ & $\mathrm{~N}$ & 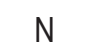 & & & 4 & 0.50 \\
\hline os2 & 0 & -3 & 0. & 2 & 0.64 & -3 & 0.53 \\
\hline os3 & & -3 & & $\mathrm{~N}$ & $\mathrm{~N}$ & & 0.54 \\
\hline P1 & & 1 & & & & & 0.45 \\
\hline P1 & & 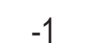 & & 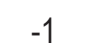 & & 1 & -0.68 \\
\hline P3 & 0 & -3 & 0. & 1 & 0. & -3 & 0.70 \\
\hline P3 & 0 & -1 & -0.57 & -1 & -0.76 & -1 & -0.64 \\
\hline P5 & 0 & $\mathrm{~N}$ & 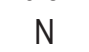 & 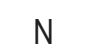 & $\mathrm{N}$ & -3 & 0 \\
\hline P5 & OC & $\mathrm{N}$ & $\mathrm{N}$ & -1 & -0.55 & -1 & -0.49 \\
\hline P1 & $O$ & 0 & 0.44 & 0 & 0.65 & 0 & 0.68 \\
\hline P1 & OC & $\mathrm{N}$ & 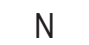 & $\Lambda$ & $\mathrm{N}$ & -3 & -0.49 \\
\hline P3 & $O C$ & 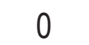 & 0.59 & 0 & 0 & 0 & 0.75 \\
\hline P3 & $\mathrm{OC}$ & -3 & -0.57 & -2 & -0.50 & -3 & -0.63 \\
\hline P5 & $\mathrm{OC} 2$ & 0 & 0.52 & 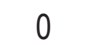 & 0.60 & 0 & 0.69 \\
\hline P5 & $\mathrm{OC} 2$ & $\mathrm{~N}$ & $\mathrm{~N}$ & -2 & -0.45 & -3 & -0.55 \\
\hline |DT1| & OC1 & $\mathrm{N}$ & 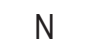 & $\mathrm{N}$ & $\mathrm{N}$ & $\mathrm{N}$ & $\mathrm{N}$ \\
\hline |DT2| & $\mathrm{OC2}$ & $\mathrm{N}$ & $\mathrm{N}$ & $\mathrm{N}$ & $\mathrm{N}$ & $\mathrm{N}$ & $\mathrm{N}$ \\
\hline$T(e x t)$ & OC & $\mathrm{N}$ & $\mathrm{N}$ & $\mathrm{N}$ & $\mathrm{N}$ & -2 & $-0.39^{\text {(d) }}$ \\
\hline $\mathrm{T}(\mathrm{ext})$ & $\mathrm{OC2}$ & $\mathrm{N}$ & $\mathrm{N}$ & $\mathrm{N}$ & $\mathrm{N}$ & $\mathrm{N}$ & $\mathrm{N}$ \\
\hline
\end{tabular}

(a) stationary data detrended by CMA of $3^{\text {rd }}$ order;

${ }^{(b)}$ stationary data detrended by CMA of $5^{\text {th }}$ order;

(c) stationary data detrended by $\mathrm{PN}$ of $4^{\text {th }}$ order;

(d) $p>0.05$

$r$ - correlation coefficient; $\mathrm{N}$ - uncorrelated; T(ext) - external temperature; TSi - air temperature in the i-soil; AHSi - absolute humidity of i-soil air; negative lag means variable delay, positive lag means variable preceding; $\mathrm{N}$ - uncorrelated

\section{$\mathrm{CO}_{2}$ dynamics}

Trends of the non-stationary segments of the $\mathrm{CO}_{2}$ time series (the autumn and spring periods) reflect $\mathrm{CO}_{2}$ dynamics in the cave sites and soils. Slopes of the autumn segments ranged from $-9.99 \times 10^{-4}$ to $-3.55 \times 10^{-}$ $3 \%$ vol. day ${ }^{-1}$ (soils) and from $-1.32 \times 10^{-3}$ to $-1.82 \times 10^{-3}$ $\%$ vol. day ${ }^{-1}$ (cave sites). The spring segments, on the other hand, correspond to the slopes from $1.56 \times 10^{-3}$ to $1.91 \times 10^{-3} \%$ vol. day ${ }^{-1}$ (soils) and from $9.04 \times 10^{-4}$ to $1.16 \times 10^{-3} \%$ vol. day ${ }^{-1}$ (cave sites) (Tab. 4).

Based on the slopes, overall fluxes were calculated as relevant increments/decrements of the $\mathrm{CO}_{2}$ contents in the soils and cave sites. Firstly, the overall $\mathrm{CO}_{2}$ fluxes into/from the cave were calculated such as the change in the $\mathrm{CO}_{2}$ content in the total volume of the given cave site. The resulting values were normalized 
Table 4. Slopes of the $\mathrm{CO}_{2}$-time series at different seasons

\begin{tabular}{|c|c|c|c|c|c|c|}
\hline \multirow[b]{2}{*}{ Site } & \multicolumn{3}{|c|}{-------------------- Autumn decrease ----------------- } & \multicolumn{3}{|c|}{ 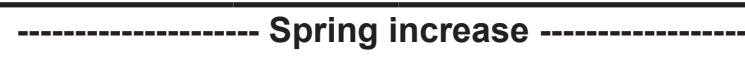 } \\
\hline & $\begin{array}{c}\text { Slope } \\
\text { [vol. \%/day] }\end{array}$ & $\mathbf{R}^{2}$ & Data segment & $\begin{array}{c}\text { Slope } \\
\text { [vol. \%/day] }\end{array}$ & $\mathbf{R}^{2}$ & Data segment \\
\hline $\mathrm{S} 1$ & $-3.55 \times 10^{-3}$ & 0.966 & 28-Sep to 08-Dec-06 & $1.91 \times 10^{-3}$ & 0.978 & 26-Mar to 30-Jun-06 \\
\hline S2 & $-9.99 \times 10^{-4}$ & 0.955 & 28-Sep to 21-Dec-06 & $2.43 \times 10^{-3}$ & 0.974 & 30-Apr to 14-Jul-06 \\
\hline S3 & $-1.46 \times 10^{-3}$ & 0.929 & 28-Sep to 21-Dec-06 & $1.56 \times 10^{-3}$ & 0.983 & 14-Apr to 14-Jul-06 \\
\hline C1 & $-1.82 \times 10^{-3}$ & 0.924 & 28-Sep to 8-Dec-06 & $9.04 \times 10^{-4}$ & 0.997 & 14-Apr to 14-Jul-06 \\
\hline $\mathrm{C} 2$ & $-1.32 \times 10^{-3}$ & 0.957 & 14-Oct to 8-Dec-06 & $1.16 \times 10^{-3}$ & 0.912 & $14-A p r$ to $14-J u l-06$ \\
\hline
\end{tabular}

Table 5. Overall $\mathrm{CO}_{2}$-fluxes into/from the individual cave sites and soils in different seasons

\begin{tabular}{ccccccc}
\hline Overall $\mathrm{CO}_{2}$-flux & Season & $\mathrm{S} 1$ & $\mathrm{~S} 2$ & $\mathrm{~S} 3$ & $\mathbf{C 1}$ & $\mathbf{C 2}$ \\
\hline $\mathrm{J}\left[\mathrm{mol} \mathrm{m}^{-2} \mathrm{~s}^{-1}\right]$ & Autumn & $-5.14 \times 10^{-10}$ & $-2.06 \times 10^{-10}$ & $-7.54 \times 10^{-10}$ & $-5.96 \times 10^{-8}$ & $-8.19 \times 10^{-8}$ \\
$\mathrm{~J}\left[\mathrm{~mol} \mathrm{~m}^{-2} \mathrm{~s}^{-1}\right]$ & Spring & $2.76 \times 10^{-10}$ & $5.02 \times 10^{-10}$ & $8.06 \times 10^{-10}$ & $3.27 \times 10^{-8}$ & $7.19 \times 10^{-8}$ \\
\hline $\mathrm{J}$ - overall $\mathrm{CO}_{2}^{- \text {flux }}$ & & & & & &
\end{tabular}

to a unitary area based on perpendicular projection from the surface to the cave site. The fluxes associated with the $\mathrm{C} 1$ and $\mathrm{C} 2$ cave sites were $-5.96 \times 10^{-8}$ and $-8.19 \times 10^{-8} \mathrm{~mol} \mathrm{~m}^{-2} \mathrm{~s}^{-1}$ during the autumn decrease, and $3.27 \times 10^{-8}$ and $7.19 \times 10^{-8} \mathrm{~mol} \mathrm{~m}^{-2} \mathrm{~s}^{-1}$ during the spring increase, respectively (Tab. 5).

In case of soils, the overall $\mathrm{CO}_{2}$ fluxes normalized to $1 \mathrm{~m}^{2}$ surface area were calculated such as the change in $\mathrm{CO}_{2}$ content in a soil prism of $1 \mathrm{~m}^{2}$ base and of a height equal to the actual soil profile depth. Air volume of the prism was estimated from soil air-filled porosity (Tab. 2). Based on different soils, the resulting overall fluxes vary from $-2.06 \times 10^{-10}$ to $-7.54 \times 10^{-10} \mathrm{~mol}$ $\mathrm{m}^{-2} \mathrm{~s}^{-1}$ during autumn and from $2.76 \times 10^{-10}$ to $8.06 \times 10^{-}$ ${ }^{10} \mathrm{~mol} \mathrm{~m}^{-2} \mathrm{~s}^{-1}$ during spring, respectively (Tab. 5).

\section{Dripwater chemistry}

The concentrations of species in the dripwater samples reflect the composition of the pure Devonian limestones of the Moravian Karst. Pollutants such as nitrates or phosphates do not exceed standard values. The positive values of the saturation index (calculated using PHREEQC) in a range from 0.23 to 1.03 (Tab. 6) indicate that all the dripwaters are supersaturated with respect to calcite. The values of $\mathrm{CO}_{2}$ partial pressures in dripwater $\left(10^{-2.98}\right.$ to $\left.10^{-2.37}\right)$ exceeded the $\mathrm{CO}_{2}$ partial pressures in the cave atmosphere $\left(10^{-3.25}\right.$ to $10^{-2.55}$ ) (Tab. 6). This predicates further dripwater degassing from $\mathrm{CO}_{2}$ and increasing supersaturation.

Principally, the dripwater composition contains information about $\mathrm{CO}_{2}$ partial pressure at water formation. The information was decoded by calculating a hypothetical $\mathrm{P}_{\mathrm{CO} 2}(\mathrm{HPP})$, at which the given dripwater would be in equilibrium with calcite. The calculation is based on a simplified model where the system air $\mathrm{CO}_{2}$ water-calcite firstly reaches equilibrium (soil, epikarst, vadose zone) and then the water comes into the cave as dripwater. Possible objections that waters on its path into cave (1) mix with each other, (2) degas, or (3) produce calcite are justified, but all the processes solely reduce the calculated HPP value. Thus, HPP represents a minimum of $\mathrm{P}_{\mathrm{CO} 2}$ that participated in the constitution of the water chemistry. The resulting HPP values for the Large Foch's Hall dripwaters vary in the range from $10^{-1.79}$ to $10^{-1.98}$. They correspond to the $\mathrm{CO}_{2}$ concentrations of $1.20 \pm 0.14 \%$ vol. (D1) and $1.37 \pm$ $0.14 \%$ vol. (D2), i.e., $1.32 \pm 0.16 \%$ vol. on average (Tab. 6). Aside from the values, some temporary drips showed concentrations up to $5 \%$ vol. of $\mathrm{CO}_{2}$ (Faimon, unpublished data).

Table 6. Source $\mathrm{CO}_{2}$-concentrations participating on constituting of the drip water chemistry

\begin{tabular}{|c|c|c|c|c|}
\hline$S I_{\text {(calcite) }}{ }^{(a)}$ & $\log P_{\mathrm{CO2DW}}{ }^{(b)}$ & $\log P_{\text {(cave atm) }}{ }^{(c)}$ & $\log$ HPP (d) & $\begin{array}{c}\mathrm{HC}_{-\mathrm{CO}_{2}{ }^{(\mathrm{e})}} \\
{[\mathrm{vol} \% \%]}\end{array}$ \\
\hline \multicolumn{5}{|c|}{ 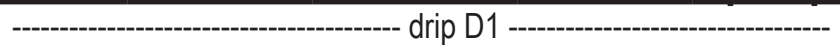 } \\
\hline 0.83 & -2.77 & -3.25 & -1.86 & 1.38 \\
\hline 0.23 & -2.43 & -3.17 & -1.98 & 1.05 \\
\hline 0.51 & -2.51 & -3.08 & -1.92 & 1.20 \\
\hline 0.59 & -2.58 & -2.99 & -1.93 & 1.17 \\
\hline 0.52 & -2.37 & -2.55 & -1.79 & 1.62 \\
\hline 0.55 & -2.44 & -2.67 & -1.83 & 1.48 \\
\hline 0.83 & -2.76 & -2.94 & -1.85 & 1.41 \\
\hline 0.90 & -2.90 & -3.03 & -1.92 & 1.20 \\
\hline 1.02 & -2.97 & -3.18 & -1.86 & 1.38 \\
\hline 1.03 & -2.98 & -3.25 & -1.86 & 1.38 \\
\hline 0.47 & -2.41 & -3.17 & -1.89 & 1.29 \\
\hline 0.63 & -2.60 & -3.08 & -1.91 & 1.23 \\
\hline
\end{tabular}

(a) calcite saturation index

(b) logarithm of partial pressure of $\mathrm{CO}_{2}$ in dripwater

(c) logarithm of partial pressure $\mathrm{CO}_{2}$ in cave atmosphere

(d) logarithm of hypothetical partial pressure of $\mathrm{CO}_{2}$ participating on water chemistry (epikarst)

(e) decoded hypothetical $\mathrm{CO}_{2}$-concentrations in epikarst

\section{Anthropogenic $\mathrm{CO}_{2}$ contribution}

The air exhaled by humans contains 2.0-5.8\% vol. $\mathrm{CO}_{2}$ (Byrnes et al., 1997), depending on physical activity (Iwamoto et al., 1994), gender (Sciacca et al., 2002), and age (Tormo et al., 2001). The air volume exhaled by a person varies over an extremely wide range from 6 to $100 \mathrm{~L} \mathrm{~min}^{-1}$, depending on activity (Iwamoto et al., 1994; Smith, 1997). Based on the 


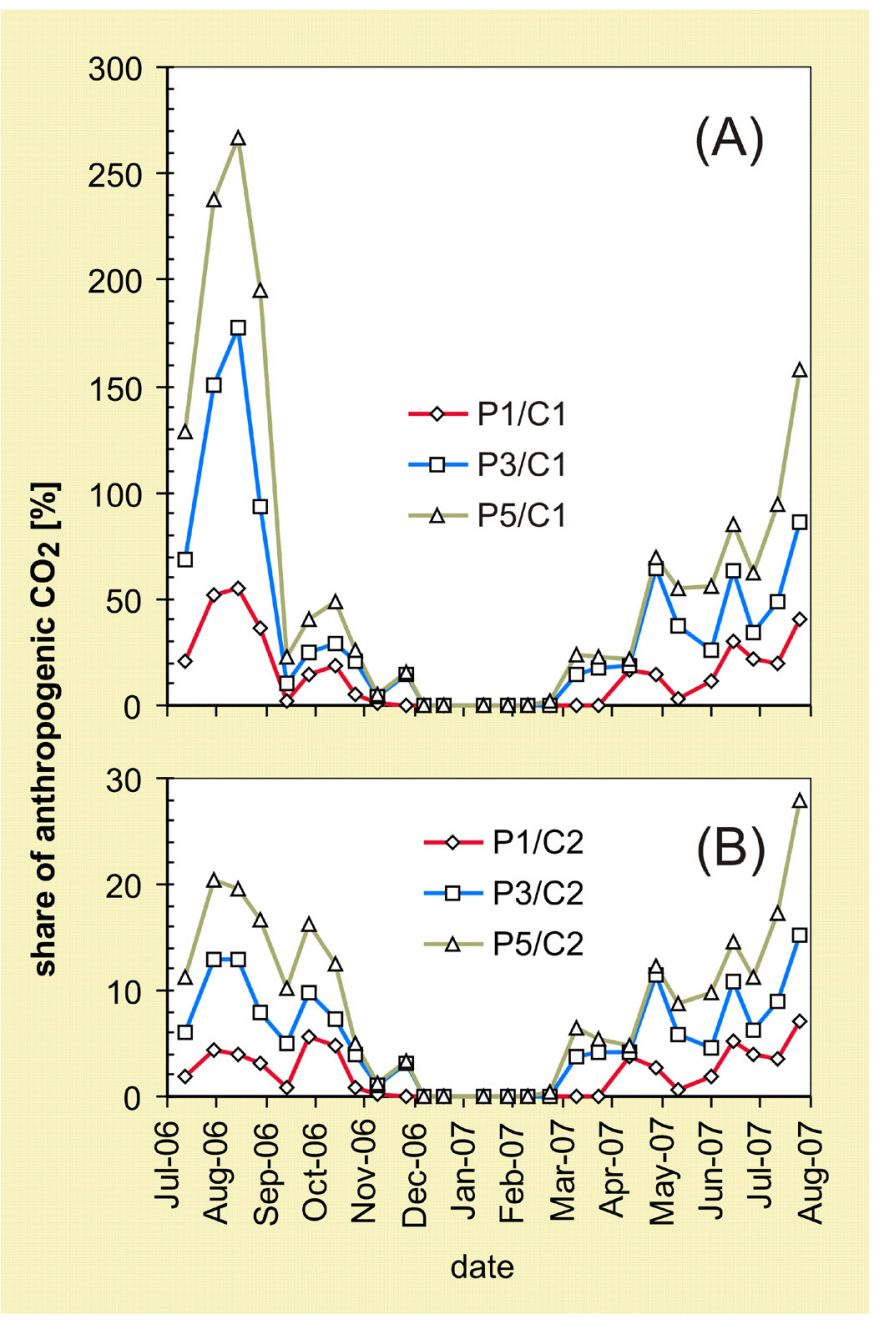

Fig. 5. Theoretically reachable relative contents of anthropogenic $\mathrm{CO}_{2}$ in the Balcarka Cave sites $\mathrm{C} 1(\mathrm{~A})$ and $\mathrm{C} 2(\mathrm{~B})$, depending on the numbers of visitors $\mathrm{P} 1, \mathrm{P} 3$, and $\mathrm{P} 5$.

assumption that one person in the cave exhaled an air volume of $15 \mathrm{~L} \mathrm{~min}^{-1}$ with $3 \%$ vol. $\mathrm{CO}_{2}$ concentration, the share of anthropogenic $\mathrm{CO}_{2}$ in the total cave $\mathrm{CO}_{2}$ may be significant, depending on the number of persons, visiting time, and cave site volume/position. Assuming a visiting time of two minutes in $\mathrm{C} 1$ and ten minutes in $\mathrm{C} 2$, we calculated that the cave $\mathrm{CO}_{2}$ could include up to $50 \%(\mathrm{P} 1)$ or even $100 \%(\mathrm{P} 3, \mathrm{P} 5)$ of anthropogenic $\mathrm{CO}_{2}$ in the small $\mathrm{C} 1$ (Fig. 5A). In the large $\mathrm{C} 2$, the cave $\mathrm{CO}_{2}$ could include up to $7 \%(\mathrm{P} 1)$, $15 \%$ (P3), or $28 \%$ (P5) of anthropogenic $\mathrm{CO}_{2}$ (Fig. 5B).

\section{DISCUSSION}

Historically, soils are believed to be the main sources of exogenous $\mathrm{CO}_{2}$ in karst. Even though the significance of soil $\mathrm{CO}_{2}$ for karstification is unquestionable, its direct effect on cave processes such as speleothem growth is less obvious.

\section{SOIL CO2}

\section{Interrelations between individual soil levels}

The individual soils somewhat differ in $\mathrm{CO}_{2}$ levels. The highest $\mathrm{CO}_{2}$ concentrations in anthropogenic soils were expected because of soil cultivating, fertilizing, and enhanced organic matter content. A concern exists about the negative impact of land use on the karst system/processes, especially via (i) changes in soil texture, moisture, and hydraulic conductivity (Canora et al., 2008; Chen et al., 2009), (ii) soil erosion (Febles et al., 2009), (iii) water pollution (Jiang et al., 2008), and (iv) a complex of influences (Baker \& Genty, 1998; Balák et al., 1999). With respect to carbon dioxide, however, we do not recognize a fundamental problem. Even though enhanced anthropogenic soil $\mathrm{CO}_{2}$ levels undoubtedly participate on a greater karst surface denudation (enhanced karstification), they could paradoxically support cave speleothem growth due to higher carbonate mineralization of resulting karst waters. The ratio of the $\mathrm{CO}_{2}$ levels in natural soils is somewhat surprising: the levels in the shallow meadow soil exceed systematically the levels in the deeper and more humic forest soil.

The results show that correlations between some variables are dependent on detrending methods. We believe that just the correlations based on the data detrended by the $3^{\text {rd }}$ order CMA (SD-CMA-3) are most relevant. The $5^{\text {th }}$ order CMA probably averages too much extensive part of the data set with respect to its total extent ( 26 data points). The polynomial detrending is less credible due to subjectively chosen polynomial order.

Correlation analysis of soil $\mathrm{CO}_{2}$ levels based on the SD-CMA-3 set shows positive correlations between individual soil $\mathrm{CO}_{2}$ levels. It means that both natural soils behave similarly despite different (1) local positions, (2) vegetation covers, and (3) sub-types. This indicates rather a decisive influence of external conditions on $\mathrm{CO}_{2}$ production. No radical impact of vegetation was recognized. In turn, similar behavior of the natural soil shows that the precise associating of the surface site to the cave lying below is not a critical operation when searching for soil/cave interrelations. Generally, a relation between both soil and cave sites is complicated, because of the inclination of $\mathrm{CO}_{2}$ paths (fissures and joints).

\section{Control of soil $\mathrm{CO}_{2}$ levels}

A wide consensus exists that soil $\mathrm{CO}_{2}$ levels are controlled by temperature and moisture (see Davidson et al., 1998; or Fang \& Moncrieff, 2001 and references therein). Based on our detrended data, however, no correlations between soil $\mathrm{CO}_{2}$ levels and air temperature/humidity were found. More exactly, even though the trends in soil air temperature/ humidity and soil $\mathrm{CO}_{2}$ level are consistent, the shortterm fluctuations do not correlate. It indicates that the detailed relations in the chain external conditions (temperature/humidity) - microbial activity - organic matter degradation ( $\mathrm{CO}_{2}$ production) is complex and still poorly understood. We believe that detail studies of diurnal variations of soil $\mathrm{CO}_{2}$ levels in dependence on external conditions may help better understanding the problem.

In general, the level of i-component in a reservoir is given by balancing all the fluxes of the component into/out of the reservoir. The increment/decrement of the reservoir content corresponds to an overall flux (the flux sign means flux direction, plus into reservoir, minus out of reservoir). The overall flux into/out of reservoir would equal the net flux of the component, if other fluxes were neglected. For example, the 
spring overall flux into soil (soil $\mathrm{CO}_{2}$ concentration increment) would correspond to a net soil production, if efflux from the soil were negligible. The autumn overall flux from the soil (the soil $\mathrm{CO}_{2}$ concentration decrement) would correspond to efflux from soils, if $\mathrm{CO}_{2}$ production were zero (e.g., due to temperature drop). The calculated overall fluxes $\pm(2$ to 8$) \times 10^{-10} \mathrm{~mol}$ $\mathrm{m}^{-2} \mathrm{~s}^{-1}$ are lower by four orders than e.g. the net $\mathrm{CO}_{2}-$ efflux $\sim 10^{-6} \mathrm{~mol} \mathrm{~m}^{-2} \mathrm{~s}^{-1}$ directly measured by others authors (Jassal et al., 2005; Keith \& Wong, 2006; Fenn et al., 2010; Kim et al., 2010). The difference indicates rather balanced fluxes and soil steady state concentrations instead of one predominant flux.

\section{Cave $\mathrm{CO}_{2}$}

The cave $\mathrm{CO}_{2}$ levels in the range of 0.1-0.3\% vol. are consistent with earlier results from Pennsylvanian (Troester \& White, 1984), Belgian (Ek \& Gewelt, 1985), Austrian (Spötl et al., 2005), Texan (Banner et al., 2007), and Irish caves (Baldini et al., 2008). The strong seasonality indicates that the $\mathrm{CO}_{2}$ levels are controlled by seasonally dependent variables.

\section{Sources of cave $\mathrm{CO}_{2}$}

Generally, five sources of cave $\mathrm{CO}_{2}$ may be postulated: (1) soils, (2) epikarst, (3) cave visitors, (4) cave sediments, and (5) endogenous sources. The last two sources (cave sediments and endogenous sources) were not considered in the present study due to their low importance in the Balcarka Cave. Note that only the first source (soils) comprises an actual climatic signal.

The correlations based on SD-MCA-3 indicate that both OS1 and OS3 could be sources of OC1. The delay of OC1 about one month (lag -2) after the soil $\mathrm{CO}_{2}$ seems reasonable. From the two sources, OS1 may be excluded as a source due to its long distance (exceeding 4-times the rock overburden thickness) from the $\mathrm{C} 1$ site. The soil $\mathrm{S} 2$ as a source appears improbable. As a source of OC2, the soils S2 and S3 are most favored due to the relatively strong correlation at the reasonable lag. The correlations of the soil $\mathrm{S} 1$ that is spatially closest to the cave site $\mathrm{C} 2$ is not convincing.

The dripwater modeling proved that the $\mathrm{CO}_{2}$ concentrations participating in the dripwater chemistry (HPP) clearly exceed the $\mathrm{CO}_{2}$ concentrations measured directly in the soils. In addition, the variation coefficient of the annual HPP data (11.9\%) is substantially lower than that one of annual soil $\mathrm{CO}_{2}$ concentrations (32-35\%). This indicates the lower seasonality of HPP, which agrees with the idea that $\mathrm{CO}_{2}$ is produced under near constant temperature conditions in epikarst (Atkinson, 1977; Fairchild et al., 2000; Spötl et al., 2005). In fact, an alternative explanation exists that the lower variability results from a mixing of different aged waters in the vadose zone. Actually, HPP can be influenced by various processes such as water degassing, calcite precipitation, or water mixing. However, all these processes merely diminish the HPP value. Thus, the HPP represents a conservative estimation of $\mathrm{CO}_{2}$ levels that has participated in dripwater formation during limestone dissolution. Regardless of the possibility of a small systematical error in directly measuring soil
$\mathrm{CO}_{2}$ concentrations (e.g., the volume of the drilled soil probe enhances the actual volumes of soil pores by 1-3\%), the modeling indicates a dominant $\mathrm{CO}_{2}$ source in the deeper epikarst zone. This is consistent with the recent study by Benavente et al. (2010) who measured in situ in the vadose zone up to $6 \%$ vol. of $\mathrm{CO}_{2}$. Shallow karst soils probably play a secondary role as minor sources. This is important for paleoclimatic reconstruction: epikarstic conditions will only slowly respond to climatic changes.

The estimates of the anthropogenic contribution suggested that the $\mathrm{CO}_{2}$ produced by visitors can be a significant source of cave $\mathrm{CO}_{2}$ (Fig. 5). The share of anthropogenic $\mathrm{CO}_{2}$ in the total $\mathrm{CO}_{2}$ content in the cave depends on visitor numbers, visiting time, cave site volume, and cave ventilation. The relevance of the anthropogenic source in cave site $\mathrm{C} 2$ is supported by the strong correlation of $\mathrm{OC} 2$ with the visitor numbers P1, P3, and P5 without a lag. In the case of the C1 site, the correlation is less conclusive. This indicates control by other variables, but does not exclude the anthropogenic source.

Occasionally, a concern appears about the risk resulting from an inversion of speleothem growth into corrosion by water enriched in anthropogenic $\mathrm{CO}_{2}$ (e.g., Baker \& Genty, 1998). However, the dripwater data analysis showed that $\mathrm{P}_{\mathrm{CO} 2}$ in the cave atmosphere remains lower than $\mathrm{P}_{\mathrm{CO} 2}$ in the water, and, hence, the dripwater (1) will degas from excess $\mathrm{CO}_{2}$ and (2) will increase supersaturation with respect to calcite. This shows that anthropogenic $\mathrm{CO}_{2}$ in the Balcarka Cave does not present any risk in this sense. The conclusion is consistent with the results of Faimon et al. (2006) obtained in Císařská Cave (Moravian Karst). However, it should be reminded that any $\mathrm{CO}_{2}$ concentration would participate in corrosion if dissolved in condensed water (see, e.g., de Freitas \& Schmekal, 2006).

\section{Control of cave $\mathrm{CO}_{2}$ levels}

The idea that karst soils control karst processes such as speleothem growth by constituting both percolating water chemistry and cave $\mathrm{CO}_{2}$ levels seems oversimplified. Instantaneous $\mathrm{CO}_{2}$ levels in the cave are given by balancing of (1) $\mathrm{CO}_{2}$ fluxes from relevant sources into the cave and (2) $\mathrm{CO}_{2}$ fluxes out of the cave by airflows (ventilation). Whereas all the sources, the soil, epikarstic, and anthropogenic ones probable operate in the study site, the ventilation effect is less evident. It is well known that cave airflows are controlled by the temperature gradients between external and cave temperatures (De Freitas et al., 1982; Faimon et al., 2011). Because ventilation reduces $\mathrm{CO}_{2}$ concentrations, the negative correlation was expected between $|\mathrm{DTi}|$ and OCi. Based of the statistical analysis, however, no correlations were found. This is surprising because comparison of the actual cave $\mathrm{CO}_{2}$ levels with the potential ones resulting from $\mathrm{P} 3$ and $\mathrm{P} 5$ values (Fig. 5) indicate that ventilation must participate on the actual levels. An explanation of slight/missing temperature dependence could be the periodic cave door opening by visitors that controls ventilation instead temperature. The hypothesis is consistent with correlation analysis that has shown some negative correlations between P1/P3/P3 and 
$\mathrm{CO}_{2}$ levels both in the $\mathrm{C} 1$ site (near the entrance) at low delay (lag -1) and in the $\mathrm{C} 2$ site (deeper in cave) at longer delay (lag -2 to -3). The door opening effect is also visible in Fig. 3, where the local $\mathrm{CO}_{2}$ minima on July-August 06 are consistent with the attendance maxima.

\section{Cave - soil interrelation}

As shown in Tab. 5, the overall $\mathrm{CO}_{2}$ fluxes into/ out of the cave sites and into/out of soils differ by more than two orders. However, a direct comparison is possible only in the case of net fluxes. To visualize the $\mathrm{CO}_{2}$ dynamics better, a conceptual model of the soilepikarst-cave system is proposed (Fig. 6). It consists of the reservoirs of soil, epikarst, and cave $\mathrm{CO}_{2}$ with the concentrations $\mathrm{OS}, \mathrm{OE}$, and $\mathrm{OC}$, respectively. The arrows between the reservoirs denote $\mathrm{CO}_{2}$ fluxes. The fluxes $\mathrm{J}_{\mathrm{Sp}}, \mathrm{J}_{\mathrm{Ep}}, \mathrm{J}_{\mathrm{atm}}$, and $\mathrm{J}_{\mathrm{A}}$ represent soil production, epikarst production, efflux into external atmosphere, and anthropogenic flux, respectively. The fluxes $\mathrm{J}_{\mathrm{v}}{ }^{0}$ and $\mathrm{J}_{\mathrm{v}}$ are associated with cave ventilation. The $\mathrm{J}_{\mathrm{S}-\mathrm{E}}, \mathrm{J}_{\mathrm{E}-\mathrm{C}}$, and $\mathrm{J}_{\mathrm{S}-\mathrm{C}}$ are exchange fluxes between the individual reservoirs. They are direct (diffusive ones, driven by concentration gradients) or indirect (convective ones, dissolved in percolating water).

Based on the analysis of $\mathrm{CO}_{2}$ dynamics, the overall $\mathrm{CO}_{2}$ flux out of cave by ventilation in autumn would correspond to a net flux, if the all fluxes into the cave were negligible. The requirement is roughly consistent with the soil $\mathrm{CO}_{2}$ minima and low attendance, but inconsistent with invariant epikarstic source. The overall flux into cave during spring would represent a net $\mathrm{CO}_{2}$ flux into cave, if ventilation were negligible. The ventilation could be indeed reduced under given temperature conditions when $\mathrm{T}_{\text {exterior }}>\mathrm{T}_{\text {cave }}$ (see e.g., Fernandez-Cortes et al., 2006), but enhanced by anthropogenic impact (by door opening).

One important question is if soils themselves (without an epikarstic source) are capable of producing the cave $\mathrm{CO}_{2}$ content. If we take the overall flux into

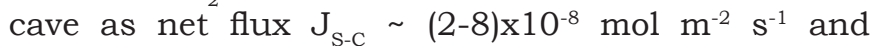
compare its with the published fluxes into atmosphere $\mathrm{J}_{\mathrm{atm}} \sim(1-10) \times 10^{-6} \mathrm{~mol} \mathrm{~m}^{-2} \mathrm{~s}^{-1}$ (Jassal et al., 2005; Keith \& Wong, 2006; Fenn et al., 2010; Kim et al., 2010), it is obvious that the soil production $\mathrm{J}_{\mathrm{Sp}}$ must only slightly exceed $\mathrm{J}_{\mathrm{atm}}$. To cover the cave input flux, the $\mathrm{CO}_{2}$ fluxes into basement would be lower than the $\mathrm{CO}_{2}$ efflux into exterior by a factor of 100 . To solve the model more precisely, soil $\mathrm{CO}_{2}$ production, efflux into the exterior, and cave ventilation must be known in addition to both the soil and cave $\mathrm{CO}_{2}$ levels. For exact solution of complete model, the additional knowledge of epikarst $\mathrm{CO}_{2}$ levels and production is necessary.

\section{Concluding notes}

The presented work should be understood as a preliminary study that rather reveals important questions than gives definite answer. Its limitation is the prevailing statistical approach and the data sets with relative long time steps between individual measurements. We believe that continuous monitoring of the current variables with some additional ones, as cave radon levels or cave air circulation rates in the future will help us to obtain a more reliable model of carbon dioxide exchange between karst reservoirs.

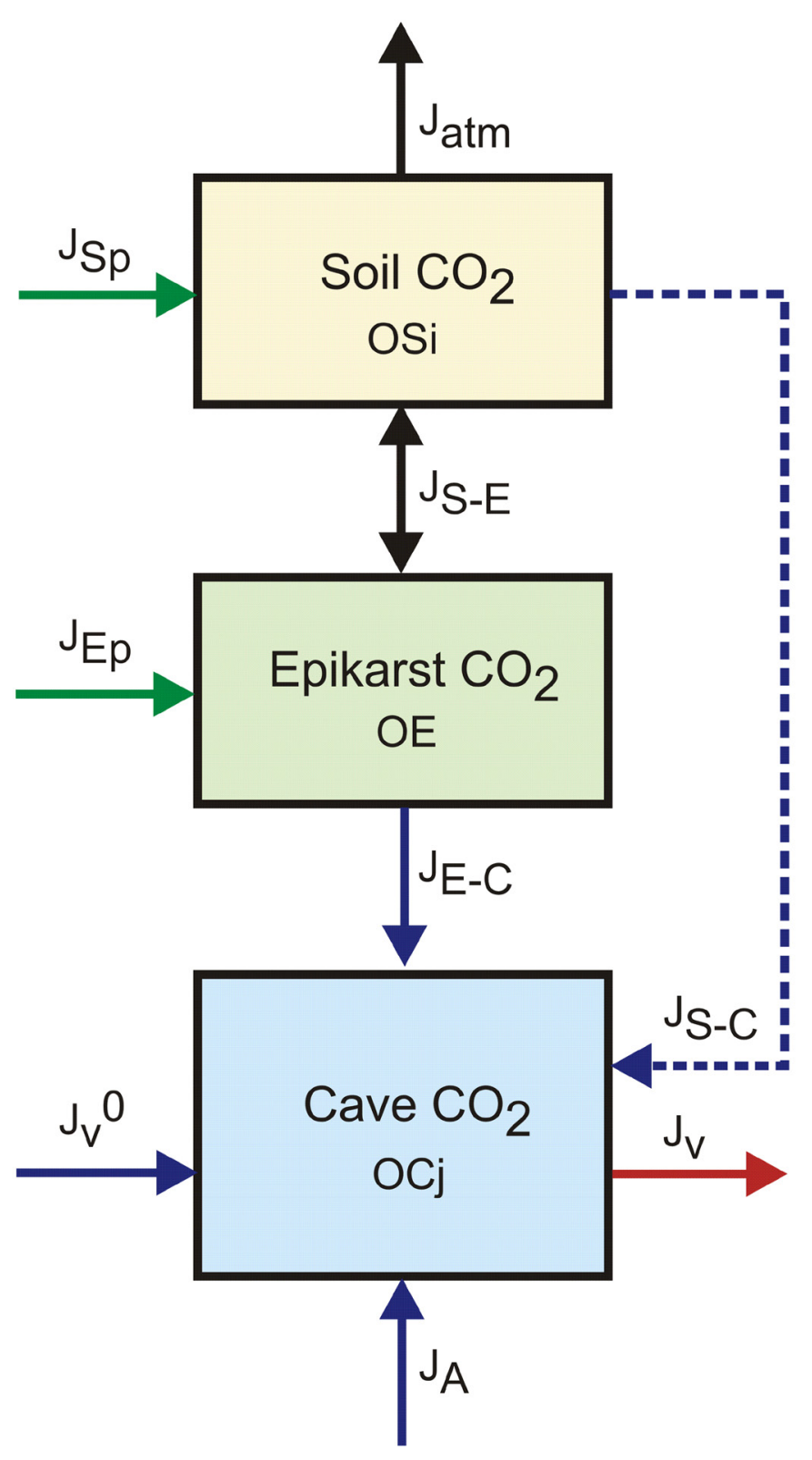

Fig. 6. A conceptual model of carbon dioxide in the soil-epikarstcave system. The reservoirs correspond to i-soil, epikarst, and cave j-site $\mathrm{CO}_{2}$ at the concentrations $\mathrm{OSi}, \mathrm{OE}$, and $\mathrm{OCj}$, respectively. The arrows between the reservoirs denote $\mathrm{CO}_{2}$ fluxes. The fluxes $\mathrm{J}_{\mathrm{SP}}, \mathrm{J}_{\mathrm{Ep}}$, and $\mathrm{J}_{\mathrm{A}}$ represent soil, epikarst, and anthropogenic $\mathrm{CO}_{2}$ production, respectively. $J_{\text {atm }}$ is efflux into external atmosphere. The fluxes $\mathrm{J}_{\mathrm{v}}{ }^{0}$ and $\mathrm{J}_{\mathrm{v}}$ are associated with cave ventilation. The $\mathrm{J}_{\mathrm{S}-\mathrm{E}}, \mathrm{J}_{\mathrm{E}-\mathrm{C}}$, and $\mathrm{J}_{\mathrm{S}-\mathrm{c}}$ are exchange fluxes between the individual reservoirs.

\section{CONCLUSIONS}

The $\mathrm{CO}_{2}$ levels in the karst soils showed typical seasonality with a maximum in summer (up to $0.5 \%$ vol.) and a minimum in winter (between 0.1 and 0.2 $\%$ vol.). The $\mathrm{CO}_{2}$ concentrations in the anthropogenic soil exceeded those ones in both natural soils and confirmed anthropogenic soil uniqueness. The behaviors of the natural soils were similar regardless of vegetation cover. No direct dependence was found between the soil $\mathrm{CO}_{2}$ levels and soil temperature/ humidity, despite similar trends. It indicates still little understood relations in $\mathrm{CO}_{2}$ production by microbial degradation of organic matter. The $\mathrm{CO}_{2}$ concentrations in two monitored sites in Balcarka Cave showed seasonality analogical to the soils: high 
concentrations in summer (up to $0.3 \%$ vol.) and low concentrations in winter (about $0.1 \%$ vol.). In contrast to the cave and soils, there were identified the concentrations up to $1.6 \%$ vol. of $\mathrm{CO}_{2}$ that had to participate on dripwater composition.

In addition to supposed soils, another two $\mathrm{CO}_{2}$ sources were identified in the cave sites: an epikarstic one and anthropogenic one. Even though the analysis of $\mathrm{CO}_{2}$ dynamics confirmed that soils could be capable source of cave $\mathrm{CO}_{2}$, the epikarstic and anthropogenic sources seem to be at least equally significant. The instantaneous $\mathrm{CO}_{2}$ concentrations in the cave are affected by human. Whereas the natural $\mathrm{CO}_{2}$ sources are strengthened by visitor breathing, natural cave ventilation is superimposed by door opening. Regardless of the anthropogenic impact, the study indicates that speleothem composition/growth rates need not necessarily reflect the external climatic conditions if neither cave $\mathrm{CO}_{2}$ levels nor dripwater hydrochemistry are controlled by soil $\mathrm{CO}_{2}$. As cave $\mathrm{CO}_{2}$ level is seasonally dependent variable, however, this conclusion requires further careful verification. The results of the study could be important for the paleoenvironmental reconstructions using speleothems as terrestrial proxies of paleoclimate.

\section{ACKNOWLEDGEMENTS}

We would like to thank Dr. Petr Štěpánek from the Czech Hydrometeorological Institute, Regional Office Brno, and Jiři Hebelka, director of the Administration of the Moravian Karst Caves, Blansko, for providing the data on regional temperatures and attendance of open caves, respectively. Two anonymous reviewers and Dr. Chris de Freitas are thanked for valuable comments. The work was supported by the MSM0021622412 grant from the Ministry of Education, Youth and Sports of the Czech Republic.

\section{REFERENCES}

Alvarez-Ramirez J., Rodriguez E. \& Echeverría J.C., 2005 - Detrending fluctuation analysis based on moving average filtering. Physica A, 354: 199-219. http://dx.doi.org/10.1016/j.physa.2005.02.020

Arnold K.V., Weslien P., Nilsson M., Svensson B.H. \& Klemedtsson L., 2005 - Fluxes of $\mathrm{CO} 2, \mathrm{CH} 4$ and $\mathrm{N} 2 \mathrm{O}$ from drained coniferous forests on organic soils. Forest Ecology Management, 210: 239-254. http://dx.doi.org/10.1016/j.foreco.2005.02.031

Atkinson T.C., 1977 - Carbon dioxide in the atmosphere of the unsaturated zone: an important control of groundwater hardness in limestones. Journal of Hydrology, 35: 111-123. http://dx.doi.org/10.1016/0022-1694(77)90080-4

Baker A. \& Genty D., 1998 - Environmental pressures on conserving cave speleothems: effects of changing surface land use and increased cave tourism. Journal of Environmental Management, 53: 165-175. http://dx.doi.org/10.1006/jema.1998.0208

Balák I., Jančo J., Štefka L. \& Bosák P., 1999 - Agriculture and nature conservation in the Moravian Karst (Czech Republic). International Journal of Speleology, 28B: 71-88.
Baldini J.U.L., Baldini L.M., McDermott F. \& Clipson N., 2006 - Carbon dioxide sources, sinks, and spatial variability in shallow temperate zone caves: Evidence from Ballynamintra Cave, Ireland. Journal of Cave and Karst Studies, 68: 4-11.

Baldini J.U.L., McDermott F., Hoffmann D.L., Richards D.A. \& Clipson N., 2008 - Very high-frequency and seasonal cave atmosphere PCO2 variability: Implications for stalagmite growth and oxygen isotope-based paleoclimate records. Earth and Planetary Science Letters, 272: 118-129. http://dx.doi.org/10.1016/j.eps1.2008.04.031

Baldocchi D., Falge E., Gu L.H., Olson R., Hollinger D., Running S., Anthoni P., Bernhofer C., Davis K., Evans R., Fuentes J., Goldstein A., Katul G., Law B., Lee X.H., Malhi Y., Meyers T., Munger W., Oechel W., U KTP, Pilegaard K., Schmid H.P., Valentini R., Verma S., Vesala T., Wilson K. \& Wofsy S., 2001 - FLUXNET: A new tool to study the temporal and spatial variability of ecosystem-scale carbon dioxide, water vapor, and energy flux densities. Bulletin of the American Meteorological Society, 82(11): 2415-2434. http://dx.doi.org/10.1175/1520-0477(2001) 082<2415:FANTTS > 2.3.CO;2

Banner J.L., Guilfoyle A., James E.W., Stern L.A. \& Musgrove M., 2007 - Seasonal variations in modern speleothem calcite growth in Central Texas, USA. Journal of Sedimentary Research, 77: 615-622 http://dx.doi.org/10.2110/jsr.2007.065

Batiot-Guilhe C., Seidel J.-L., Jourde H., Hébrard O. \& Bailly-Comte V., 2007 - Seasonal variations of $\mathrm{CO} 2$ and 222Rn in a mediterranean sinkhole spring (Causse d'Aumelas, SE France). International Journal of Speleology, 36 (1): 51-56.

Benavente J., Vadillo I., Carrasco F., Soler A., Lián C. \& Moral F. 2010 - Air carbon dioxide contents in the vadose zone of a Mediterranean karst. Vadose Zone Journal, 9 (1): 126-136.

http://dx.doi.org/10.2136/vzj2009.0027

Bourges F., Mangin A. \& d'Hulst D., 2001 - Le gaz carbonique dans la dynamique de l'atmosphère des cavités karstiques: l'exemple de l'Aven d'Orgnac (Ardèche). Comptes Rendus de l'Academie des Sciences Paris, Earth and Planetary Sciences, 333: 685-692, Paris.

Byrnes C.A., Dinarevic S., Busst C., Bush A. \& Shinebourne E.A., 1997 - Is nitric oxide in exhaled air produced at airway or alveolar level? European Respiratory Journal, 10: 1021-5. http://dx.doi.org/10.1183/09031936.97.10051021

Canora F., Fidelibus M.D., Sciortino A. \& Spilotro G., 2008 - Variation of infiltration rate through karstic surfaces due to land use changes: A case study in Murgia (SE-Italy). Engineering Geology, 99: 210- 227. http://dx.doi.org/10.1016/j.enggeo.2007.11.018

Chen X., Zhang Z. \& Shi P., 2009 - The impact of land use and land cover changes on soil moisture and hydraulic conductivity along the karst hillslopes of southwest China. Environmental Earth Sciences, 59: 811-820.

http://dx.doi.org/10.1007/s12665-009-0077-6 
Davidson E.A., Belk E. \& Boone R.D., 1998 - Soil water content and temperature as independent or confounded factors controlling soil respiration in a temperate mixed hardwood forest. Global Change and Biology, 4: 217-227. http://dx.doi.org/10.1046/j.1365-2486.1998.00128.x

Denis A. \& Crémoux F., 2002 - Using the entropy of curves to segment a time or spatial series. Mathematical Geology, 34(8): 899-914. http://dx.doi.org/10.1023/A:1021302922108

Denis A., Lastennet R., Huneau F. \& Malaurent P., 2005 - Identification of functional relationships between atmospheric pressure and $\mathrm{CO} 2$ in the cave of Lascaux using the concept of entropy of curves. Geophysical Research Letters, 32: L05810, http://dx.doi.org/10.1029/2004GL022226

de Freitas, C.R. \& Schmekal A., 2006 - Studies of condensation/evaporation processes in the Glowworm Cave, New Zealand. International Journal of Speleology, 35(2): 7581.

de Freitas C.R., Littlejohn R.N., Clarkson T.S. \& KristamentI.S., 1982-Caveclimate:Assessment ofairflow and ventilation. Journal of Climatology, 2:383-397. http://dx.doi.org/10.1002/joc.3370020408

Dreybrodt W., 1999 - Chemical kinetics, speleothem growth and climate. Boreas, 28: 347-356. http://dx.doi.org/10.1111/j.1502-3885.1999.tb00224.x

Ek C. \& Gewelt M., 1985 - Carbon dioxide in cave atmospheres. New results in Belgium and comparison with some other countries. Earth Surface Processes and Landforms, 10: 173-187. http://dx.doi.org/10.1002/esp.3290100209

Faimon J., Štelcl J. \& Sas D., 2006 - Anthropogenic CO2- flux into cave atmosphere and its environmental impact: A case study in the Císařská Cave (Moravian Karst, Czech Republic). Science of the Total Environment, 369: 231-245. http://dx.doi.org/10.1016/j.scitotenv.2006.04.006

Faimon J. \& Ličbinská M., 2010 - Carbon dioxide in the soils and adjacent caves of the Moravian Karst. Acta Carsologica, 39/3: 463-475.

Faimon J., Troppová D., Baldík V. \& Novotný R., 2011 - Air circulation and its impact on microclimatic variables in the Císařská Cave (Moravian Karst, Czech Republic). International Journal of Climatology, 31: DOI: 10.1002/joc.2298. http://dx.doi.org/10.1002/joc. 2298

Fairchild I.J., Borsato A., Tooth A.F., Frisia S., Hawkesworth C.J., Huang Y., McDermott F. \& Spiro B., 2000 - Controls on trace element (Sr-Mg) compositions of carbonate cave waters: implications for speleothem climatic records. Chemical Geology, 166: 255-269. http://dx.doi.org/10.1016/S0009-2541(99)00216-8

Fairchild I.J., Smith C.L., Baker A., Fuller L, Spötl C., Mattey D., McDermott F. \& EIMF, 2006 - Modification and preservation of environmental signals in speleothems. Earth-Science Reviews, 75: 105-153. http://dx.doi.org/10.1016/i.earscirev.2005.08.003

Fang C. \& Moncrieff J.B., 2001 - The dependence of soil $\mathrm{CO} 2$ efflux on temperature. Soil Biology and Biochemistry, 33: 155-165. http://dx.doi.org/10.1016/S0038-0717(00)00125-5
Febles J.M., Tolón A. \& Vega M. B., 2009 - Edaphic indicators for assesment of soil erosion in karst regions, province of Havana, Cuba. Land Degradation and Development, 20: 522-534. http://dx.doi.org/10.1002/ldr.929

Fenn K.M., Malhi Y. \& Morecroft M.D., 2010 - Soil CO2 efflux in a temperate deciduous forest: Environmental drivers and component contributions. Soil Biology and Biochemistry, 42(10): 1685- 1693. http://dx.doi.org/10.1016/j.soilbio.2010.05.028

Fernandez-Cortes A., Calaforra J.M. \& SanchezMartos F., 2006 - Spatiotemporal analysis of air conditions as a tool for the environmental management of a show cave (Cueva del Agua, Spain). Atmospheric Environment, 40: 7378-7394. http://dx.doi.org/10.1016/j.atmosenv.2006.06.045

Helsel D.R. \& Frans L.M., 2006 - Regional Kendall test for trend. Environmental Science Technology, 40(13): 4066-4073,

http://dx.doi.org/10.1021/es051650b

Helsel D.R., Mueller D.K. \& Slack J.R., 2006 - Computer Program for the Kendall Family of Trend Test . Report: 2005-5275. U.S. Geological Survey Scientific, 4 pp.

Helsel D.R. \& Hirsch R.M., 2002 - Statistical Methods in Water Resources. U.S. Geological Survey Techniques of Water-Resources Investigations, A3: 524 pp. Available online at: http://water.usgs.gov/pubs/twri/twri4a3/

Hirsch R.M., Slack J.R. \& Smith R.A., 1982 - Techniques of trend analysis for monthly water quality data. Water Resources Research, 18: 107- 121. http://dx.doi.org/10.1029/WR018i001p00107

Hirsch R.M. \& Slack J.R., 1984 - A nonparametric trend test for seasonal data with serial dependence. Water Resources Research, 20: 727-732. http://dx.doi.org/10.1029/WR020i006p00727

Holland H.D., Kirsipu T.V., Huebner J.S. \& Oxburgh U.M., 1964 - On some aspects of the chemical evolution of cave water. Journal of Geology, 72: 36-67. http://dx.doi.org/10.1086/626964

Iqbal J., Ronggui H., Lijun D., Lan L., Shan L., Tao C. \& Leilei R., 2008 - Differences in soil CO2 flux between different land use types in mid-subtropical China. Soil Biology and Biochemistry, 40: 2324- 2333. http://dx.doi.org/10.1016/j.soilbio.2008.05.010

IUSS Working Group WRB, 2007 - World Reference Base for Soil Resources 2006, first update 2007. World Soil Resources Reports No. 103. FAO, Rome. http://www.fao.org/ag/agl/agll/wrb/doc/ wrb2007 corr.pdf

Iwamoto J., Pendergast D.R., Suzuki H. \& Krasney J.A., 1994 - Effect of graded exercise on nitric oxide in expired air in humans. Research in Physiology, 97: 333-45. http://dx.doi.org/10.1016/0034-5687(94)90069-8

Jassal R.S., Black T.A., Drewitt G.B., Novak M.D., Gaumont-Guay D. \& Nesic Z., 2005 A model of the production and transport of $\mathrm{CO} 2$ in soil: predicting soil $\mathrm{CO} 2$ concentrations and $\mathrm{CO} 2$ efflux from forest floor. Agricultural and Forest Meteorology, 124: 219-236. http://dx.doi.org/10.1016/j.agrformet.2004.01.013 
Jiang Y., Zhang C., Yuan D., Zhang G. \& He R., 2008 Impact of land use change on groundwater quality in a typical karst watershed of southwest China: a case study of the Xiaojiang watershed, Yunnan Province. Hydrogeology Journal, 16: 727-735. http://dx.doi.org/10.1007/s10040-007-0259-9

Jungkunst H.F., Flessa H., Scherber C. \& Fiedler S., 2008 - Groundwater level controls CO2, N2O and $\mathrm{CH} 4$ fluxes of three different hydromorphic soil types of a temperate forest ecosystem. Soil Biology and Biochemistry, 40: 2047-2054.

http://dx.doi.org/10.1016/j.soilbio.2008.04.015

Kaufmann G. \& Dreybrodt W., 2007 - Calcite dissolution kinetics in the system CaCO3-H2O- $\mathrm{CO} 2$ at high undersaturation. Geochimica et Cosmochimica Acta, 71: 1398-1410. http://dx.doi.org/10.1016/j.gca.2006.10.024

Keith H. \& Wong S.C., 2006 - Measurement of soil CO2 efflux using soda lime absorption: both quantitative and reliable. Soil Biology and Biochemistry, 38: 1121-1131. http://dx.doi.org/10.1016/j.soilbio.2005.09.012

Kim D.-G., Mu S., Kang S. \& Lee D., 2010 - Factors controlling soil $\mathrm{CO} 2$ effluxes and the effects of rewetting on effluxes in adjacent deciduous, coniferous, and mixed forests in Korea. Soil Biology and Biochemistry, 42: 576-585.

http://dx.doi.org/10.1016/j.soilbio.2009.12.005

Kuzyakov Y., 2006 - Sources of CO2 efflux from soil and review of partitioning methods. Soil Biology and Biochemistry, 38: 425-448.

http://dx.doi.org/10.1016/j.soilbio.2005.08.020

Kuzyakov Y. \& Larionova A.A., 2005 - Root and rhizomicrobial respiration: A review of approaches to estimate respiration by autotrophic and heterotrophic organisms in soil. Journal of Plant Nutrition and Soil Science, 168: 503-520.

http://dx.doi.org/10.1002/jpln.200421703

Li H.J., Yan J.X., Yue X.F. \& Wang M.B., 2008 - Significance of soil temperature and moisture for soil respiration in a Chinese mountain area. Agricultural and Forest Meteorology, 148: 490-503. http://dx.doi.org/10.1016/j.agrformet.2007.10.009

Longdoz B., Yernaux M. \& Aubinet M., 2008 - Soil $\mathrm{CO} 2$ efflux measurements in a mixed forest: impact of chamber disturbances, spatial variability and seasonal evolution. Global Change and Biology, 6: 907-917.

http://dx.doi.org/10.1046/j.1365-2486.2000.00369.x

Miotke F-D., 1974 - Carbon dioxide and the soil atmosphere. Abhandlungen zur Karst-Und Höhlenkunde, Reihe A, Speläologie, Heft 9, p. 49.
Parkhurst D.L. \& Appelo C.A.J, 1999 - User`s guide to PHREEQC - a computer program for speciation, batch - reaction, one dimensional transport, and inverse geochemical calculations. U. S. Geol. Surv., Denver, Colorado, USA.

http://water.usgs.gov/software

Piao H.C., Wu Y.Y., Hong Y.T. \& Yuan Z.Y., 2000 Soil-released carbon dioxide from microbial biomass carbon in the cultivated soils of karst areas of southwest China. Biology and Fertility of Soils, 31: 422-426.

http://dx.doi.org/10.1007/s003749900189

Reynolds W.D., Drury C.F., Yang X.M., Fox C.A., Tan C.S. \& Zhang T.Q., 2007 - Land management effects on the near-surface physical quality of a clay loam soil. Soil Tillage Research, 96: 316-330. http://dx.doi.org/10.1016/j.still.2007.07.003

Sciacca J., Forbes W.M., Ashton F.T., Lombardini E., Gamble H.R. \& Schad G.A., 2002 - Response to carbon dioxide by the infective larvae of three species of parasitic nematodes. Parasitology International, 51: 53-62.

http://dx.doi.org/10.1016/S1383-5769(01)00105-2

Smith G.K., 1997 - Foul air in limestone caves and its effect on cavers. Proceedings of the 21st biennial Australian Speleological Federation conference, vol. 1997, p. 48-58.

Spötl C., Fairchild I.J. \& Tooth A.F., 2005 - Cave air control on dripwater geochemistry, Obir Caves (Austria): Implications for speleothem deposition in dynamically ventilated caves. Geochimica et Cosmochimica Acta, 69(10): 2451-2468. http://dx.doi.org/10.1016/j.gca.2004.12.009

Tatár E., Mihucz V.G., Tompa K., Pöppl L., Záray G. \& ZambóL., 2004-Studyofsoilleachatesindolineabove the Béke Cave, Hungary. Geoderma, 120: 155-164. http://dx.doi.org/10.1016/j.geoderma.2003.09.001

Tormo R., Bertaccini A., Conde M., Infante D. \& Cura I., 2001 - Methane and hydrogen exhalation in normal children and in lactose malabsorption. Early Human Development, 65: S165-72 [Supp1]. http://dx.doi.org/10.1016/S0378-3782(01)00219-5

Troester J.W. \& White W.B., 1984 - Seasonal Fluctuations in the Carbon Dioxide Partial Pressure in a Cave Atmosphere. Water Resources Research, 20: $153-156$.

http://dx.doi.org/10.1029/WR020i001p00153 